\section{IAfLL- Lä̈̈HETIETEELLUNELI AIHAHAUSLEHTI}

Journal of Social Medicine

Päätoimittaja

Riikka Lämsä

riikka.lamsa@helsinki.fi

Toimitussihteeri

Jenna Grundström

toimitussihteeri@socialmedicine.fi

Lehden internetsivut

http://journal.fi/sla

Julkaisija

Sosiaalilääketieteen yhdistys ry

Socialmedicinska föreningen rf

Julkaisijan osoite

Sosiaaliläketieteen yhdistys

c/o Paula Jääskeläinen

PL 9 (Siltavuorenpenger IA)

00014 Helsingin yliopisto

Yhdistyksen puheenjohtaja

Hannamaria Kuusio

Terveyden ja hyvinvoinnin laitos

PL 30

0027I Helsinki

Yhdistyksen sihteeri

Laura Pääkkö

sihteeri@socialmedicine.fi

Ilmestymisaikataulu

Neljä numeroa vuodessa (helmikuu, toukokuu, syyskuu ja joulukuu)

Kirjapaino ja taitto

Kirjapaino Hermes Oy

Tämä julkaisu on saanut TSV:n kautta tieteellisen julkaisutoiminnan avustusta, jota opetus- ja kulttuuriministeriö myöntää Veikkauksen tuotoista

ISSN 0355-5097

Kirjapaino Hermes Oy 2021
P屍比们们比

2/2021

58. VUOSIKERTA

\title{
Huomio palliatiivisen hoidon kehittämiseen
}

Palliatiivisella hoidolla tarkoitetaan parantumattomasti sairaan potilaan ja hänen läheisensä aktiivista ja kokonaisvaltaista hoitoa. Palliatiivinen hoito on ihmisoikeus, joka pitää turvata kaikille sitä tarvitseville iästä, asuinpaikasta tai hoitavasta tahosta riippumatta. Palliatiivisesta hoidosta on julkaistu jo jonkin aikaa sitten Käypä hoito -suositus (1) ja sosiaali- ja terveysministeriön (STM) suositus palvelujen tuottamisesta ja laadun parantamisesta (2). Tavoitteena on yhdenvertainen hoito, joka on kaikkien sitä tarvitsevien saatavilla. Kehittämisen keskeisiä teemoja ovat käytäntöjen yhtenäistäminen ja osaamisen lisääminen. Paikoitellen kehittämistyö on lähtenyt hitaasti käyntiin eivätkä rakenteet ja toiminta kaikilta osilta täytä STM:n suositusten laatukriteereitä. Siksi kehittämistyötä tarvitaan edelleen.

Kansallisesti palliatiivisen hoidon palvelujärjestelmää kehitetään osana Tulevaisuuden sosiaali- ja terveyskeskus -ohjelmaa ja tietopohjaa Terveyden ja hyvinvoinnin laitoksen (THL) vetämässä Palliatiivisen hoidon ja saattohoidon laatutieto -hankkeessa (3). Laatutieto -hankkeen tavoitteena on luoda mahdollisuuksia hoidon laadun ja suositusten toteutumisen seurantaan valtakunnallisesti yhtenäisellä tavalla ja ohjata palveluntuottajia tarjoamaan entistä laadukkaampaa ja vaikuttavampaa elämän loppuvaiheen hoitoa. Samalla kehitetään tietopohjaa valtakunnallisen laaturekisterin pohjaksi. Parhaillaan hankkeessa suunnitellaan pilottitutkimusta uusien palliatiivisen hoidon toimenpidekoodien testaamiseen erityistason yksiköissä ja työstetään seurantaindikaattoreita sosiaali- ja terveydenhuoltoon sekä laatukäsikirjaa toiminnan kehittämiseksi ja laadun parantamiseksi. Lisäksi projektissa arvioidaan, millaista laatutietoa elämän loppuvaiheen 
hoidosta on saatavilla nykyisten tietosisältöjen kautta ja miten sitä voidaan käyttää seurantaindikaattorien muodostamisessa.

Palliatiivisen hoidon järjestämisen kulmakivenä ovat palliatiiviset keskukset, jotka koordinoivat alueiden palveluketjuja ja huolehtivat, että sairaanhoitopiireillä on palliatiivisen hoidon suunnitelmat palveluketjukuvauksineen.

Palliatiivisten kotisairaaloiden perustaminen ja kehittäminen vahvistavat palliatiivisen hoidon perustasoa, parantavat palvelun saatavuutta ja siten kansalaisten yhdenvertaisuutta alueellisesti. Kotisairaalat tarjoavat lääkärijohtoista, sairaalatasoista ja ympärivuorokautista hoitoa potilaan kotiin tai esimerkiksi asumispalveluyksikköön. Toimintaan kuuluvat kotisairaalalle nimetyt tukiosastot, jonne potilas voi tarvittaessa siirtyä ilman erillistä lähetettä tai käyntiä päivystyksessä. Erityistason palliatiivisen hoidon jalkauttaminen kotihoidon ja ympärivuorokautisen hoidon tueksi auttaa välttämään rasittavia ja tarpeettomia siirtoja päivystykseen ja sairaalaan.

Lämsän ym. tutkimus osoitti, että onnistunut palliatiivinen hoito kotisairaalassa edellyttää hoitohenkilökunnan kouluttautumista, sosiaalityön, fysioterapian ja psykiatrisen sairaanhoitajan palvelujen sisällyttämistä kotisairaalan palveluvalikoimaan, aktiivista tiedollista ja taidollista tukea potilasta hoitaville läheisille sekä läheisten jaksamisesta huolehtimista (4). Palvelun toteuttamiseksi tarvitaan palliatiiviseen hoitoon ja kivunhoitoon erikoistuneita tiimejä, perustasoa tukevia erityistason konsultaatiopalveluja ja erikoissairaanhoidon palliatiivisten poliklinikkapalveluiden lisäämistä. Myös teknologian ja digitalisaation mahdollisuuksia palveluiden saatavuuden parantamisessa tulisi hyödyntää entistä paremmin.

Sisällöllisesti hoidon laatua pyritään kehittämään henkilöstön osaamista vahvistamalla. Opetus- ja kulttuuriministeriön rahoittamassa EduPal-hankkeessa (5) lääkäreille ja sairaanhoitajille on tehty perusopetuksen valtakunnalliset opetus- suunnitelmasuositukset palliatiivisen hoidon ja saattohoidon opetuksesta. Suositusten tavoitteena on yhdenmukaistaa lääkäreiden ja sairaanhoitajien palliatiivisen hoidon osaamista. THL:ssa on avattu valtakunnallinen Saattohoitopassi-täydennyskoulutusverkkokurssi, joka on kohdennettu erityisesti perustason palliatiivisen hoidon parissa toimiville terveyden- ja sosiaalihuollon ammattilaisille (6). Tässä Sosiaalilääketieteellisessä aikakauslehdessä julkaistaan Mäenpään ym. artikkeli, jossa tarkastellaan potilaiden ja läheisten kokemuksia lääkärien palliatiivisen ja saattohoidon hoidon osaamisesta.

Myös vammaisten henkilöiden palliatiiviseen hoitoon liittyvien erityistarpeiden kartoittaminen on käynnissä, ja saattohoitoon liittyviä lainsäädännön muutostarpeita selvitetään. Asiantuntijoiden näkemyksiä palliatiivisen hoidon ja saattohoidon kehittämis- ja tutkimustarpeista löytyy tästä lehdestä Salin ym. artikkelista.

Palliatiivista hoitoa on jatkossa pystyttävä toteuttamaan sosiaali- ja terveydenhuollon eri palveluissa ja hoidon eri tasoilla. Joka tapauksessa rakenteiden ja palveluiden kehittämisen keskiössä tulee olla potilas ja hänen läheisensä. Hyvä elämän loppuvaiheen hoito perustuu ihmisen omiin tarpeisiin ja toiveisiin. Laadukas hoito edellyttää, että elämän loppuvaiheen ennakoiva hoitosuunnitelma tehdään yhdessä potilaan ja tarvittaessa hänen läheistensä kanssa jo hyvissä ajoin. Palvelut tulee rakentaa joustavasti ja kokonaisvaltaisesti erilaisten elämäntilanteiden ja yksilöllisten tarpeiden ympärille.

Lisää keskustelua aiheesta Sosiaalilääketieteellisen aikakauslehden podcastissa (soundcloud. com/sosiaalilääketieteellinen aikakauslehti).

Teija Hammar

Johtava asiantuntija

Terveyden ja hyvinvoinnin laitos

RiIKKA LÄMSÄ

Päätoimittaja

Sosiaalilääketieteellinen aikakauslehti 
(1) Duodecim. Palliatiivinen hoito ja saattohoito. Käypä hoito -suositus. Helsinki: Suomalainen Lääkäriseura Duodecim; 2019. Luettu 10.5.2021. https://www.kaypahoito.fi/hoi50063\#K1

(2) Saarto T, Finne-Soveri H. Suositus palliatiivisen hoidon palveluluiden tuottamisesta ja laadun parantamisesta Suomessa. Palliatiivisen hoidon asiantuntijaryhmän loppuraportti. Helsinki, STM; 2019. Luettu 10.5.2021. https://julkaisut. valtioneuvosto.fi/handle/10024/161946

(3) THL. Palliatiivisen hoidon ja saattohoidon laatutieto -projekti. Luettu 10.5.2021. https:// thl.fi/fi/tutkimus-ja-kehittaminen/tutkimukset-jahankkeet/palliatiivisen-hoidon-ja-saattohoidontila-suomessa/palliatiivisen-hoidon-jasaattohoidon-laatutieto-projekti
(4) Lämsä R, Niemi M, Seppänen M. Koti sairaalana. Onnistuneen kotisairaalatoiminnan edellytykset. Helsinki: KAKS; 2021. https:// kaks.fi/julkaisut/koti-sairaalana-onnistuneenkotisairaalatoiminnan-edellytykset/

(5) OKM. Palliatiivisen koulutuksen kehittäminen. Luettu 10.5.2021. https://www. palliatiivisenkoulutuksenkehittaminen.fi/

(6) THL. Saattohoitopassi. Luettu 10.5.2021. https:// thl.fi/fi/web/ikaantyminen/elaman-loppuvaiheenhoito/hoidon-kehittaminen-tutkimus-ja-koulutus/ saattohoitopassi-verkkokurssi 